\title{
Construction of Chromosomal In-Frame Deletion Mutants in Rhodobacter capsulatus
}

\author{
Molly M. Leung and John Thomas Beatty ${ }^{*}$
}

Department of Microbiology and Immunology, University of British Columbia, Vancouver, Canada *For correspondence: jbeatty@interchange.ubc.ca

[Abstract] Markerless chromosomal in-frame deletion mutants are often used to avoid polar effects, conserve antibiotic resistance markers or make multiple mutations. This protocol capitalizes on the sacB gene (lethal in the presence of sucrose), for selection against a single cross-over event, on a suicide vector (contains no Rhodobacter capsulatus compatible origin of replication). The bacterial strains, media and suicide vectors in this protocol are specific for $R$. capsulatus, but the concepts can be applied to other species.

\section{Materials and Reagents}

1. R. capsulatus recipient strain

2. RCV broth

3. RCV agar

4. Sucrose

5. L-malic acid (Sigma-Aldrich, catalog number: 240176)

6. Thiamine hydrochloride (Sigma-Aldrich, catalog number: T1270)

7. Escherichia coli cloning strain capable of conjugation (e.g. S17-1)

8. Suicide plasmid, such as pZJD29A (Z. Jiang and C. E. Bauer, unpublished strain construction), that contains the $\operatorname{sac} B$ gene and an antibiotic resistance gene, but no Rhodobacter capsulatus compatible origin of replication. The suicide plasmid pZJD29A is a derivative of pJP5603 and has a RK6-based origin of replication making it a "universal" suicide plasmid (Penfold and Pemberton, 1992)

9. Appropriate antibiotic (resistance specified by the suicide plasmid)

10. RCV broth/agar (Beatty and Gest, 1981) (see Recipes)

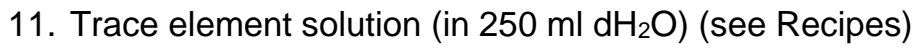

\section{Equipment}

1. $30^{\circ} \mathrm{C}$ shaker

2. $30^{\circ} \mathrm{C}$ incubator

3. Test tubes 
4. Petri plates

\section{Procedure}

1. Subclone $\sim 1 \mathrm{~kb}$ of upstream sequences plus the first several codons of the gene to be deleted into pUC19 or similar vector. In the resulting plasmid, clone the last several codons of the gene to be deleted plus $\sim 1 \mathrm{~kb}$ of downstream sequences. Amplify this whole segment by PCR and clone into a suicide plasmid (such as PZJD29A), which contains $\operatorname{sac} B$ and an antibiotic resistance gene. Be sure to design your construct so that the first and last several codons of the gene to be deleted are in-frame. This cloning is done in E. coli.

2. Conjugate the deletion construct into R. capsulatus (refer to "Bacterial Conjugation of Rhodobacter capsulatus" protocol) (Leung and Beatty, 2013).

3. Streak the conjugated $R$. capsulatus on RCV agar plate supplemented with the appropriate antibiotic (i.e. the antibiotic resistance on the suicide plasmid). Colonies that grow represent single cross-over events.

4. Confirm single cross-over event by PCR, or streaking colonies on RCV, RCV + antibiotic, and RCV $+10 \%$ sucrose. They should grow on RCV and RCV + antibiotic, but not RCV + $10 \%$ sucrose because the sacB gene results in toxicity in the presence of sucrose and only single crossover events will maintain the $s a c B$ gene.

5. Inoculate $10 \mathrm{ml}$ of RCV (NO antibiotic) with a colony that is confirmed to have a single cross-over and incubate at $30^{\circ} \mathrm{C}$, shaking at $250 \mathrm{rpm}$ for 3-5 days.

6. Spin down $1 \mathrm{ml}$ of this culture in a microcentrifuge tube, decant supernatant and resuspend cell pellet in $100 \mu \mathrm{R}$ RV broth.

7. Spread cell suspension on a RCV $+10 \%$ sucrose agar plate, incubate at $30{ }^{\circ} \mathrm{C}$ for $4-7$ days.

8. Colonies that grow should be restreaked on RCV, RCV + antibiotic, and RCV $+10 \%$ sucrose. The double cross-over (i.e. chromosomal in-frame deletion mutant) should grow on RCV and RCV + $10 \%$ sucrose but not on RCV + antibiotic because the second crossover event results in the loss of the $\operatorname{sac} B$ gene and the antibiotic resistance gene.

9. Confirm chromosomal in-frame deletion mutant by PCR because the second cross over can either result in WT or the KO, which will both grow on RCV and RCV $+10 \%$ sucrose but not on RCV + antibiotics.

\section{$\underline{\text { Recipes }}$}

1. RCV broth/agar (Beatty and Gest, 1981) (in $1 \mathrm{~L}$; autoclaved) 
$4 \mathrm{~g} \mathrm{D}$, L-malic acid

$1 \mathrm{~g}\left(\mathrm{NH}_{4}\right)_{2} \mathrm{SO}_{4}$

$10 \mathrm{mM}$ potassium phosphate buffer

$200 \mathrm{mg} \mathrm{MgSO}{ }_{4} \cdot 7 \mathrm{H}_{2} \mathrm{O}$

$75 \mathrm{mg} \mathrm{CaCl} 2 \cdot 2 \mathrm{H}_{2} \mathrm{O}$

$12 \mathrm{mg} \mathrm{FeSO}{ }_{4} \cdot 7 \mathrm{H}_{2} \mathrm{O}$

$20 \mathrm{mg} \mathrm{Na} \mathrm{N}_{2}$ EDTA

$1 \mathrm{ml}$ trace element solution

$1 \mathrm{mg}$ thiamine hydrochloride

$\mathrm{pH}$ adjusted to 6.8 with $\mathrm{NaOH}$ before autoclaving

(for agar add 1.5\% agar)

2. Trace element solution (in $250 \mathrm{ml} \mathrm{dH}_{2} \mathrm{O}$ )

$0.7 \mathrm{~g} \mathrm{H}_{3} \mathrm{BO}_{3}$

$398 \mathrm{mg} \mathrm{MnSO} 4 \cdot \mathrm{H}_{2} \mathrm{O}$

$188 \mathrm{mg} \mathrm{Na} 2 \mathrm{MoO}_{4} \cdot 2 \mathrm{H}_{2} \mathrm{O}$

$60 \mathrm{mg} \mathrm{ZnSO} \cdot \cdot 7 \mathrm{H}_{2} \mathrm{O}$

$10 \mathrm{mg} \mathrm{Cu}\left(\mathrm{NO}_{3}\right) \cdot 3 \mathrm{H}_{2} \mathrm{O}$

\section{Acknowledgments}

The development of this protocol was funded by a grant to J.T.B. from the Canadian Institutes of Health Research. This protocol was adapted from protocols developed by Beatty and Gest (1981), and Penfold and Pemberton (1992).

\section{References}

1. Beatty, J. T. and H. Gest (1981). Generation of succinyl-coenzyme A in photosynthetic bacteria. Arch Microbiol 129(5): 335-340.

2. Leung M.M., Brimacombe C.A., Spiegelman G.B., and Beatty J.T. (2012) The GtaR protein negatively regulates transcription of the gtaRI operon and modulates gene transfer agent (RcGTA) expression in Rhodobacter capsulatus. Mol Microbiol 83(4):75974.

3. Leung, M. and Beatty, J. T. (2013). Bacterial Conjugation in Rhodobacter capsulatus. Bio-protocol 3(13): e804.

4. Penfold, R.J. and Pemberton, J.M (1992). An improved suicide vector for construction of chromosomal insertion mutations in bacteria. Gene118 (1): 145-146. 